\title{
Dominick Finello
}

\author{
Ámbitos y espacios pastoriles en obras y autores áureos \\ Madrid / Frankfurt, Iberoamericana / Vervuert, 2014, 224 p. \\ Biblioteca Áurea Hispánica; 91 \\ ISBN 9788484897729
}

\section{Laura Hernández Lorenzo}

Universidad de Sevilla

lhernandez1@us.es

El profesor Dominick Finello ha publicado abundantes estudios sobre novela pastoril y, especialmente, sobre Cervantes, Gálvez de Montalvo y Lope de Vega. Es el autor, además, de otras dos monografías sobre novela pastoril, Pastoral Themes and Forms in Cervantes' Fiction (1994) y The Evolution of the Pastoral Novel in Early Modern Spain (2008), ambas reseñadas en la prestigiosa revista Hispanic Review. Su última monografía está formada por un conjunto de ensayos sobre novela pastoril. Se trata de trabajos independientes entre sí, algunos de ellos presentados previamente en diversos congresos, pero unidos por un elemento aglutinador: la reciprocidad entre el personaje literario y sus entornos. El ámbito espacial, protagonista de esta recopilación, aparece en la obra en su sentido más amplio, designando tanto espacios físicos concretos como ámbitos abstractos. A través de estos, el profesor Finello abarca la producción del género pastoril desde finales del siglo XV hasta principios del siglo XVIII para centrarse en tres aspectos fundamentales, como él mismo señala en la introducción de su obra: el papel de los entornos concretos e imaginarios en la novela pastoril, la relación entre los libros de pastores y su público y, finalmente, la tensión entre la teoría literaria y la práctica pastoril, convirtiéndose lo pastoril en un género poco abordado por la teoría literaria.

El ensayo que abre el libro, "Los paisajes y los personajes del Quijote», explora los diferentes paisajes de la obra maestra cervantina y cómo afectan o determinan a los personajes que habitan en ellos. De este modo, Finello analiza separadamente la llanura, el bosque y la montaña, la cueva y el jardín, demostrando que el personaje funciona como una extensión del lugar en el que habita, 
al tiempo que destaca la simbología de cada espacio en la obra, que mezcla paisajes históricos y ficticios. Para Finello, el Quijote representa «un gran mapa de las poblaciones», que le sirve para estudiar el carácter y la psique de los personajes de la ficción. En la llanura, destaca especialmente el motivo de la venta como lugar en el que se reúnen los solitarios viajeros de la árida llanura castellana, y que se convierte así en un medio de sociabilidad para estos. En el bosque y la montaña se desarrollan el episodio de Marcela y Grisóstomo y la aparición del desdichado Cardenio, tan asilvestrado como el paisaje montańoso que lo rodea, caracterizado por las condiciones extremas de supervivencia. Pero gracias a su aislamiento del exterior, la montańa funciona también como un refugio y aun como un laboratorio en el que don Quijote puede por fin encontrar las aventuras que persigue. Por otra parte, la cueva es el espacio personal en el que la imaginación y la capacidad creadora pueden dar lugar a nuevas invenciones, como la versión de don Quijote de "La muerte de Durandarte», episodio en el que la tradición literaria idealista se deforma hasta lo grotesco. Por el contrario, el jardín representa el entorno ideal y los cambios psicológicos vividos por los personajes dedicados a la contemplación de la circunstancia humana, que Cervantes desarrolla cuando una pastora informa a don Quijote sobre una Arcadia fingida, refugio de los jóvenes nobles.

En el siguiente ensayo, «Los paisajes y escenarios fantaseados en la segunda parte de El Quijote», el profesor Finello analiza las diferencias entre la Primera y la Segunda parte de la obra y cómo se reflejan en los espacios y personajes; destaca la mayor impronta barroca de la segunda parte, que provoca una gran aparición de paisajes e imágenes artificiales en la estela del desengaño barroco. Según el autor, esta complejidad se anuncia en algunos de los episodios de la primera parte y, especialmente, en el drama que tiene lugar en la venta, episodio en el que los personajes se burlan de don Quijote y cuyo desorden y confusión anticipan el tono de la segunda parte. Señala, además, que el episodio del Caballero del Verde Gabán constituye una excepción dentro del segundo Quijote, un «oasis humanista en medio del confuso mundo de la España barroca». Para Finello, el mundo del Quijote trata el tema de la magia y el misterio que, si bien en la primera parte aparece a través del recurso del «encantador», en la segunda se expresa a través de la teatralidad, el engaño y la ambigüedad. De este modo, el paisaje natural de la primera parte se sustituye en la segunda por sonidos e imágenes artificiales, fruto de los juegos y trucos de personajes que exageran su respuesta ante las caballerías de don Quijote. Esto se relaciona también con las invenciones mecánicas promovidas por los Habsburgo y la nobleza española. Esta complejidad se analiza a través de los escenarios grotescos de la segunda parte, con especial atención al de la cueva de Montesinos, así como en los capítulos inusualmente visuales y ruidosos protagonizados por los duques.

«La Galatea y El pastor de Fílida en el ámbito teórico" profundiza en las relaciones entre Cervantes y Gálvez de Montalvo, así como en sus respectivos enfoques de la novela pastoril, al tiempo que se aborda la problemática entre la 
teoría y la práctica del género. Este último tema sirve de nexo de unión con el siguiente ensayo, "La novela pastoril entre la temática y la teoría», donde se profundiza en esta problemática y en la defensa del género llevada a cabo por sus autores. En el primero de estos ensayos, Finello indaga en el enfoque que adoptan conjuntamente Cervantes y Gálvez de Montalvo ante un género caracterizado fundamentalmente por la falta de verosimilitud y la utilización de lo pastoril como medio para comunicarse con amigos y personas próximas. Posteriormente, analiza con más detalle la obra de Gálvez de Montalvo concluyendo que realiza una significativa contribución al subgénero pastoril «salonesco». En «La novela pastoril entre la temática y la teoría» señala los elementos fundamentales de este género, cómo los autores enfocan la falta de justificación teórica que este sufre y resalta la importancia de la corte como centro de estabilidad que acerca la novela a la actualidad de la época.

Por otra parte, en "Lope, Arcadia y sus ámbitos literarios», el profesor Finello realiza un análisis de La Arcadia (1598) de Lope de Vega y de cómo se reflejan en esta los rasgos fundamentales del género en la época, deteniéndose especialmente en el elemento cortesano y la verosimilitud. Para ello, profundiza en la vinculación de la Arcadia con Alba de Tormes, villa dotada de una vida cortesana pintada por Lope siguiendo el modelo de la Arcadia mítica, para estudiar a continuación el tratamiento del tema amoroso en la obra. Por último, en cuanto a la verosimilitud, Lope aprovecha el lugar intermedio que ocupaba la novela pastoril en el debate sobre la verdad poética del siglo xvi para extender la máscara e incluir a sus lectores y a personas conocidas dentro de la propia ficción.

Seguidamente, en "La égloga dramática hacia la comedia nueva: autonomía e integración de los ámbitos literarios», se realiza un recorrido de la evolución de la égloga dramática desde Juan del Encina hasta la comedia nueva de Lope de Vega, que resalta los títulos más importantes, junto con sus aportaciones, variaciones e innovaciones. En este género de la égloga dramática se profundiza en el ensayo que cierra el libro, "La égloga y el entorno novelesco». En el primero de estos ensayos, Finello señala cómo la égloga va progresando desde el teatro elemental al espacio teatral rústico, hasta llegar a la complejidad y madurez de la comedia barroca, con complicados escenarios, múltiples tramas y personajes reales y mitológicos. En estas transformaciones, fundamentales para la evolución del género pastoril, se subraya especialmente la importancia clave en este proceso del ambiente cortesano. En el segundo ensayo, tras unos breves pero acertados preliminares sobre la relevancia del papel de la égloga en la novela de tema bucólico, se analiza la interrelación entre estos dos géneros - y la función que ocupa la égloga - en la obra de Lope de Vega y Cervantes, lo que pone de manifiesto el hibridismo de la novela pastoril.

A lo largo de todos estos capítulos, el profesor Finello insiste especialmente en el ámbito socio-cultural de la época y su relación con lo pastoril, el cual pasa del género humilde de la tradición clásica a convertirse en un género más elevado, entre otros motivos, por su recurso de la máscara y de los cortesanos 
disfrazados de pastores, al tiempo que estos se sienten más atraídos por la lectura de un género cada vez más suyo. A lo largo de la monografía abundan, además, los ejemplos de textos pastoriles procedentes no solo de autores canónicos, sino también de autores menos conocidos. Esta reflexión otorga un carácter más general y abarcador a las conclusiones del propio autor.

Para concluir, se trata de una obra altamente recomendable para el lector interesado en la literatura áurea e imprescindible para los estudiosos de lo pastoril, cuyas claves en torno al concepto del espacio son muy acertadamente exploradas en este libro. 